\title{
PENYULUHAN TENTANG PENYUSUNAN RENCANA POLA TANAM PADA SALURAN IRIGASI DI DUSUN CITANGKOLO UNTUK MENDUKUNG PENINGKATAN PRODUKSI PERTANIAN DALAM MENANGGULANGI KEMISKINAN
}

\author{
Yanti Defiana
}

Fakultas Teknik Universitas Galuh

Email: yantideffi@yahoo.com

\begin{abstract}
ABSTRAK
Tujuan dari kegiatan pengabdian ini adalah untuk memberikan penyuluhan kepada masyarakat Dusun Citangkolo Desa Kujangsari Kota Banjar mengenai perencanaan pola tata tanam sehingga dapat menghindari ketidakseragaman tanaman, menetapkan jadwal waktu tanam agar memudahkan dalam usaha pengelolaan air irigasi, peningkatan efisiensi irigasi dan meningkatkan hasil produksi pertanian. Hasil yang diperoleh dari kegiatan pengabdian ini adalah bertambahnya wawasan para peserta penyuluhan mengenai perencanaan pola tata tanam dan tumbuh motivasi dan kesadaran akan pentingnya menerapkan pola tata tanam di lahan pertanian untuk mengoptimalkan hasil produksi tanaman pertanian.
\end{abstract}

Kata kunci: penyuluhan, rencana pola tanam, saluran irigasi, produksi pertanian

\section{PENDAHULUAN}

Air adalah sumber daya alam yang sangat penting untuk kelangsungan hidup semua makhluk hidup. Air juga sangat diperlukan untuk kegiatan industri, perikanan, pertanian dan usaha-usaha lainnya. Air irigasi di Indonesia umumnya bersumber dari sungai, waduk, air tanah dan sistem pasang surut. Dalam pemanfaatan air khususnya dalam hal pertanian, dalam rangka memenuhi kebutuhan pangan serta pengembangan wilayah, Pemerintah Indonesia melakukan usaha pembangunan di bidang pengairan yang bertujuan agar dapat langsung dirasakan oleh masyarakat dalam memenuhi kebutuhan air. Kebutuhan air yang diperlukan pada areal irigasi besarnya bervariasi sesuai keadaan. Besarnya kebutuhan air irigasi juga bergantung kepada cara pengolahan lahan. Kebutuhan air irigasi secara keseluruhan perlu diketahui karena merupakan salah satu tahap penting yang diperlukan dalam perencanaan dan pengelolaan sistem irigasi.

Salah satu usaha dalam peningkatan produksi pangan khususnya padi adalah menyediakan air irigasi di sawah-sawah sesuai dengan kebutuhan. Selain itu juga diperlukan penetapan pola tanam. Pola tanam adalah gambaran rencana tanam berbagai jenis tanaman yang akan dibudidayakan dalam suatu lahan beririgasi dalam satu tahun. Pola tata tanam yang berlaku pada setiap daerah akan berbeda dengan daerah lain, karena karakteristik setiap daerah juga berbeda. Tujuan pola tata tanam adalah untuk memanfaatkan persediaan air irigasi seefektif mungkin, sehingga tanaman dapat tumbuh dengan baik. Sedangkan tujuan dari penerapan pola tata tanam adalah menghindari ketidakseragaman tanaman, menetapkan 
Penyuluhan Tentang Penyusunan Rencana Pola Tanam pada Saluran Irigasi di Dusun Citangkolo Untuk Mendukung Peningkatan Produksi Pertanian Dalam Menanggulangi Kemiskinan

Yanti Defiana

jadwal waktu tanam agar memudahkan dalam usaha pengelolaan air irigasi, peningkatan efisiensi irigasi dan meningkatkan hasil produksi pertanian.

Kota Banjar mempunyai potensi lahan pertanian yang sangat luas. Akan tetapi dari semua potensi yang ada belum dapat dimanfaatkan secara optimal karena kurangnya data dan informasi tentang ketersediaan dan kebutuhan air yang diambil dari sungai melalui saluran irigasi. Ketersediaan dan kebutuhan tersebut harus seimbang dengan air yang tersedia di sungai untuk kebutuhan pertanian. Kebutuhan air di daerah pertanian khususnya persawahan dipengaruhi oleh beberapa faktor yaitu evapotranspirasi, perkolasi, penggantian lapisan, dan curah hujan efektif.

Saluran irigasi di Dusun Citangkolo merupakan salah satu saluran irigasi yang berada di Kota Banjar yang dibangun pada tahun 1961 dengan luas areal persawahan yang dialiri cukup besar. Mengingat posisinya yang berada di pinggir saluran irigasi, maka perlu dilakukan suatu analisis untuk mengetahui besarnya ketersediaan dan kebutuhan air irigasi untuk merencanakan pola tata tanam sehingga dapat meningkatkan dan mengoptimalkan hasil produksi pertanian di daerah tersebut.

Tujuan dari kegiatan pengabdian ini adalah untuk memberikan penyuluhan kepada masyarakat Dusun Citangkolo Desa Kujangsari Kota Banjar mengenai perencanaan pola tata tanam sehingga dapat menghindari ketidakseragaman tanaman, menetapkan jadwal waktu tanam agar memudahkan dalam usaha pengelolaan air irigasi, peningkatan efisiensi irigasi dan meningkatkan hasil produksi pertanian.

\section{BAHAN DAN METODE}

Sasaran strategis dalam kegiatan ini masyarakat Dusun Citangkolo RT 05 RW 01 Desa Kujangsari Kecamatan Langensari Kota Banjar sebanyak 40 orang yang sebagian besar berprofesi sebagai petani.

Kegiatan Pengabdian ini dilaksanakan selama 4 bulan dengan langkah-langkah sebagai berikut:

\section{a) Persiapan dan Pembekalan}

Mekanisme pelaksanaan kegiatan pengabdian ini meliputi tahapan sebagai berikut:

1. Perekrutan mahasiswa sebagai anggota pengabdian

2. Melakukan koordinasi dengan pihak desa

3. Pembuatan booklet mengenai perencanaan pola tata tanam

4. Sosialisasi waktu pelaksanaan kegiatan

5. Penyiapan sarana dan perlengkapan 
Adapun materi persiapan dan pembekalan yang diberikan kepada mahasiswa mencakup beberapa hal sebagai berikut :

1. Peran dan fungsi mahasiswa dalam program pengabdian

2. Penjelasan panduan dan pelaksanaan program pengabdian

3. Penjelasan materi penyuluhan yaitu penyusunan rencana pola tanam di saluran irigasi Citangkolo.

\section{b) Pelaksanaan}

Kegiatan pelatihan dilaksanakan dengan menggunakan metode berupa pemberian materi penyuluhan berupa booklet, pemaparan materi penyuluhan, sesi tanya jawab dan diskusi. Materi :

1. Memperkirakan debit tersedia berdasarkan data curah hujan.

2. Menghitung kebutuhan air irigasi berdasarkan luas tanam, pola tanam, dan kebutuhan air di petak sawah atau lahan usaha tani.

3. Menghitung atau mencocokkan kebutuhan air irigasi dengan debit tersedia.

4. Perencanaan pola tata tanam.

\section{c) Rencana Keberlanjutan Program}

Dalam upaya menjaga keberlanjutan pelaksanaan kegiatan pengabdian ini, terdapat beberapa perencanaan jangka panjang yang akan dilakukan. Pada awal pelaksanaan program dilakukan pemetaan terhadap potensi dan masalah yang muncul serta alternatif solusi yang dapat diambil, hasil dari pemetaan tersebut kemudian ditindak lanjuti dengan penempatan mahasiswa pada berbagai program sesuai dengan kondisi masalah yang dialami.

Dari beberapa program yang akan dijalankan keberlanjutan program nantinya dapat dilihat dari meningkatnya pemahaman masyarakat Dusun Citangkolo mengenai penyusunan dan penerapan rencana pola tanam pada saluran irigasi di Dusun Citangkolo.

\section{HASIL DAN PEMBAHASAN}

Sebagaimana telah dijelaskan sebelumnya bahwa dalam pelaksanaan kegiatan pengabdian di Dusun Citangkolo ini, adalah kegiatan pengabdian masyarakat difokuskan pada pemahaman masyarakat terhadap perencanaan pola tata tanam yang baik untuk mengoptimalkan produksi hasil tanaman pertanian. 
Penyuluhan Tentang Penyusunan Rencana Pola Tanam pada Saluran Irigasi di Dusun Citangkolo Untuk Mendukung Peningkatan Produksi Pertanian Dalam Menanggulangi Kemiskinan

Yanti Defiana

\section{Pelaksanaan Kegiatan}

Kegiatan penyuluhan ini merupakan rangkaian dari kegiatan pengabdian di Dusun Citangkolo RT 05 RW 01 Desa Kujangsari Kecamatan Langensari Kota Banjar dengan target peserta sebanyak 40 orang yang berprofesi sebagai petani. Harapan dari kegiatan ini adalah menambah wawasan yang berkaitan dengan profesi mereka. Materi yang diberikan berupa pemahaman mengenai perencanaan pola tata tanam sehingga dapat menghindari ketidakseragaman tanaman, menetapkan jadwal waktu tanam agar memudahkan dalam usaha pengelolaan air irigasi, peningkatan efisiensi irigasi dan meningkatkan hasil produksi pertanian.

\section{Evaluasi}

Dari setiap kegiatan yang dilaksanakan, maka dilakukan evaluasi pada akhir kegiatan. Evaluasi dilakukan berupa diskusi dan tanya-jawab antara pemateri dan masyarakat yang mengikuti kegiatan penyuluhan tersebut. Dari hasil diskusi dan tanya jawab tersebut dapat dilihat melalui kemampuan peserta dalam menyerap materi yang diberikan. Dari hasil diskusi dan tanya-jawab dengan peserta terlihat bahwa peserta mampu memahami materi yang telah diberikan. Peserta penyuluhan mulai mengerti dan sadar kapan jadwal waktu tanam yang tepat untuk menanami lahan pertanian mereka dengan variasi tanaman disesuaikan dengan debit air yang tersedia sehingga dapat memenuhi kebutuhan air tanaman tersebut sampai mencapai masa panen.

\section{KESIMPULAN DAN SARAN}

\section{Kesimpulan}

Dari hasil pemantauan dan evaluasi kegiatan pengabdian kepada masyarakat dengan judul "Penyuluhan Tentang Penyusunan Rencana Pola Tanam Pada Saluran Irigasi Di Dusun Citangkolo Untuk Mendukung Peningkatan Produksi Pertanian Dalam Menanggulangi Kemiskinan" dapat ditarik beberapa kesimpulan:

1. Bertambahnya wawasan para peserta penyuluhan mengenai perencanaan pola tata tanam sehingga dapat menghindari ketidakseragaman tanaman, menetapkan jadwal waktu tanam agar memudahkan dalam usaha pengelolaan air irigasi, peningkatan efisiensi irigasi dan meningkatkan hasil produksi pertanian.

2. Tumbuh motivasi dan kesadaran akan pentingnya menerapkan pola tata tanam di lahan pertanian untuk mengoptimalkan hasil produksi tanaman pertanian. 


\section{Saran}

Saran yang dapat disampaikan adalah sebagai berikut:

1. Diperlukan perhatian dari pihak pemerintah untuk lebih mensosialisaikan tentang pentingnya perencanaan pola tata tanam di suatu lahan pertanian.

2. Kegiatan penyuluhan ini harus terus dilanjutkan untuk beberapa desa di kecamatan yang lain.

\section{DAFTAR PUSTAKA}

Anonim. (1986). Buku Petunjuk Perencanaan Irigasi, Bagian Penunjang Untuk Standar Perencanaan Irigasi. Bandung: CV. Galang Persada.

Anonim. (1986). Standar Perencanaan Irigasi, Kriteria Perencanaan Bagian Jaringan Irigasi KP-01. Bandung: CV. Galang Persada.

Anggrahini. (2005). Hidrolika Saluran Terbuka. Surabaya: Srikandi.

Sosongko, D. (1986). Teknik Sumber Daya Air. Fakultas Teknik Sipil Universitas Kristen Indonesia, Jakarta.

Sosrodarsono, S. dan Kensaku Takeda. (1980). Hidrologi Untuk Pengairan. Jakarta: Pradnya Paramita.

Sudjarwadi. (1990). Teori dan Praktek Irigasi. Yogyakarta: Universitas Gajah Mada.

Suhardjono. (1994). Kebutuhan Air Tanaman. Malang: Institut Teknologi Nasional. 